\title{
Study of the Antimicrobial effect of Melia azedarach L. plant
}

\author{
Melia azedarach L. دراسه للفعالية ضد الجرثوميه لنبات السبحبح
}

\author{
Suad M Majeed \\ Biotechnology Research Center/ Al-Nahrain University \\ سعاد محمد مجيد \\ مركز بحوث الثقنيات الاحيائية / جامعة النهرين مجاد
}

\begin{abstract}
This study was aimed to evaluate the antimicrobial activity of the leaf extracts of Melia azedarach L. plant against different pathogenic microorganisms such as (Staphylococcus aureus, Pseudomonas aeruginosa, Escherichia coli, klebsilla sp., Candida albicans). Two plant extracts (Aqueous and ethanolic) under four different concentrations $(25,50,75,100) \mathrm{mg} / \mathrm{ml}$ were used by Agar-well diffusion method. Chemical detection of extract showed that the extracts contain tannins, flavonoids, terpins, steriods, alkaloids, and saponins. Aqueous leaf extract showed no effect against all tested microorganisms at $(25,50,75,100) \mathrm{mg} / \mathrm{ml}$ concentration except Candida albicans which was sensitive to $100 \mathrm{mg} / \mathrm{ml}$ concentration. While Ethanolic $(\mathbf{8 0} \%)$ leaf extract showed sensitivity on Staphylococcus aureus at $100 \mathrm{mg} / \mathrm{ml}$ concentration.
\end{abstract}

الهرفتخلص من هذه الاراسه هو تقييم القدرة التثبيطية للمستخلص المائي والكحولي لاوراق نبات السبحبح

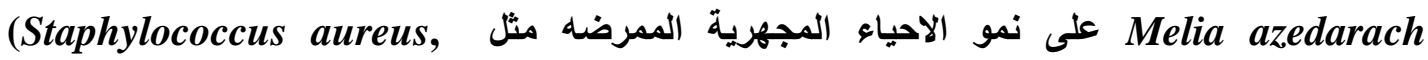
- ( Candida albicans, Pseudomonas aeruginosa, Escherichia coli, klebsilla sp وبالتراكيز (100،50،75،25)ملفم/مل وذلك باستعمال طريقة الحفر. اجري الكثف الكيميائي للنبات

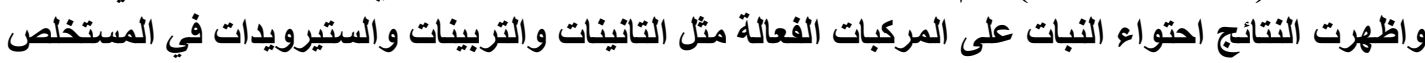

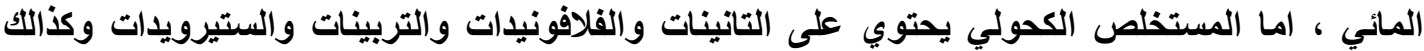

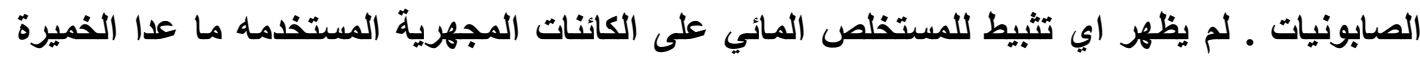
فقد ابدت تحسسها للتركيز 100 ملفم/مل ، بينما اظهرت البكتريا

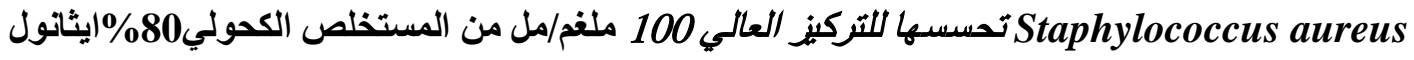

\section{Introduction}

The demand for herbal medicinal plant is growing very fast in recent years, because of the patient's immunity to medicine and its side effects [1]. The screening of plant extracts and plant products for antimicrobial activity has shown that higher plants represent potential source of antibiotic prototypes [1].

Herbal medicines are dietary supplements that contain herbs, either singly or in mixture. An herb also is a plant or plant part used for its scent, flavor, and/or therapeutic properties. Products made from botanical parts that are used to maintain or improve health are called herbal supplements, botanicals, or phytomedicines [2].

Melia azedarach Linn. belongs to (Meliaceae) family, commonly known as "Persian Lilac", is one of these important plants which contain a number of medicinally compounds [3]. M. azedarach is used orally and topically as antiparasitic and antifungal agent [4,5]. Chemical composition reveals the presence of alkaloids,

Key words: Melia azedarach; Antimicrobial activity; aqueous extract; ethanolic extract 
tannins, meliotannic acid, benzoic acid, vanillic acid, and others [6,7]. The aim of this current work was to evaluate the antimicrobial potential of $M$. azedarach extracts in different solvents against some pathogenic microorganisms.

\section{Materials and Methods}

\section{Preparation of leaf extracts}

Healthy plant leaves were collected from the University of Al-Nahrain garden, in April 2011and 2012 and identified at the Department of Biology, University of Baghdad. The leaves washed thoroughly in running tap water, 100 grams of fresh leaves of M. azedarach plant were weighed and put in conical flask with $1000 \mathrm{ml}$ of distilled water to prepare the aqueous extract, then in water bath for $2 \mathrm{hr}$ at $40^{\circ} \mathrm{C}$. The extract was filtered through whatman No.1 filter paper. The filtrate was concentrated in vacuum using rotary evaporator at $40^{\circ} \mathrm{C}$ then the extract was sterilized with millipore filter (o.22 $\mu \mathrm{m})$ [8].

$100 \mathrm{gm}$ of fresh leaves were blended with $500 \mathrm{ml}$ of alcohol (80\%ethanol) and stored at room temp. for 5 days. The extract was filtered through cheesecloth then through whatman No.1 filter paper. The filtrate was concentrated by using rotary evaporator at $45^{\circ} \mathrm{C}$. Both extracts were left at $4^{\circ} \mathrm{C}$ until used in the assay. The extraction was repeated three times.

\section{Test microorganisms}

Four strains of Gram-positive and Gram negative bacteria were used to estimate the antimicrobial activity were obtained from Biotechnology Research Center at AlNahrain University. The microbial strains used in the study were (Staphylococcus aureus, Pseudomonas aeruginosa, Escherichia coli, klebsilla sp.)

and Candida albicans.

\section{Antimicrobial assay}

Muller Hinton Agar medium (MHA) was used for the antibacterial susceptibility study. The bacterial assay was performed by agar well diffusion method [9,10]. (3.1 $\mathrm{g} / 100 \mathrm{ml}$ ) of (MHA) was weighed and dissolved in $100 \mathrm{ml}$ of distilled water, then sterilized by autoclaving and was allowed to cool at room temperature. The medium was poured into sterile Petri plates. The culture medium was inoculated with the given microorganisms by spreading the bacterial inoculums on the media. Microorganisms' concentration was $10^{2}$. Wells (6) $\mathrm{mm}$ were punched into the agar and filled with the extracts. Four different concentrations of plant extracts $(25,50,75,100) \mathrm{mg} / \mathrm{ml}$ filled the wells separately. The plates were incubated at $37^{\circ} \mathrm{C}$ for18 h. and the antibacterial activity was determined by measuring the diameters of inhibition zone in millimeter. Controls were maintained where pure solvents were used as negative controls instead of the extracts. The experiment was repeated three times and the mean values were presented.

\section{Results}

\section{Phytochemical analysis}

The preliminary phytochemical screening of different extracts was done to ascertain the presence of bioactive components. The presence of alkaloids, flavonoids, tannins, terpenes, steroids, and saponins was determined [11,12], Table (1) showed the results 
Table (1): Bioactive components of $M$. azedarach leaf extract (aqueous and ethanolic)

$\begin{array}{cr}\text { Phytochemicals } & \text { Melia az } \\ \text { Alkaloids } & + \\ \text { Flavonoids } & + \\ \text { Saponins } & + \\ \text { Steriods } & + \\ \text { Tannins } & + \\ \text { Terpins } & +\end{array}$

The results showed also that aqueous leaf extract of $M$. azedarach did not possesse antibacterial activity against tested gram positive, and gram negative bacteria (Pseudomonas aeruginosa, Staphylococcus aureus, Escherichia coli and Klebsiella pneumoniae $)$ at all concentrations $(25,50,75,100) \mathrm{mg} / \mathrm{ml}$ of aqueous and solvent leaf extract as shown in Table (2).

While the ethanolic leaf extract of $M$. azedarach showed that it possessed antibacterial activity against Staphylococcus aureus bacteria at $100 \mathrm{mg} / \mathrm{ml}$. The Pseudomonas aeruginosa, Escherichia coli and Klebsiella pneumonia were resistant to ethanolic leaf extract. While the ethanolic leaf extracts showed a slight effect on Candida albicans in aqueous leaf extracts Table (2).

Table (2): Antimicrobial potential of Melia azedarach crude leaf extracts

\begin{tabular}{|c|c|c|c|c|c|}
\hline \multirow{2}{*}{ Tested microorganisms } & \multirow[t]{2}{*}{ Extracts } & \multirow{2}{*}{\multicolumn{4}{|c|}{$\begin{array}{c}\text { concentrations }(\mathrm{mg} / \mathrm{ml}) \\
\text { Inhibition zone diameter }(\mathrm{mm})\end{array}$}} \\
\hline & & 25 & 50 & 75 & \\
\hline \multirow{4}{*}{ Pseudomonas aeruginosa } & AQ & _ & _ & - & _- \\
\hline & EA & - & _- & - & - \\
\hline & C & $\begin{array}{l}- \\
-\end{array}$ & $\begin{array}{l}- \\
-\end{array}$ & - & - \\
\hline & AQ & _ & _ & _- & - \\
\hline \multirow[t]{3}{*}{ Staphylococcus aureus } & EA & - & _- & - & 16 \\
\hline & C & - & - & - & - \\
\hline & AQ & _- & - & - & - \\
\hline \multirow[t]{3}{*}{ Escherichia coli } & EA & _- & _- & - & _- \\
\hline & C & _- & _ & _- & _- \\
\hline & $\mathbf{A Q}$ & _ & _- & - & - \\
\hline \multirow[t]{3}{*}{ klebsilla sp. } & EA & _- & _ & _- & _- \\
\hline & C & _ & _ & _- & _- \\
\hline & AQ & - & - & - & 14.5 \\
\hline \multirow[t]{2}{*}{ Candida albicans } & EA & _- & _ & - & _ \\
\hline & C & 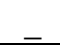 & - & 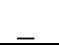 & - \\
\hline
\end{tabular}

$\mathrm{AQ}=$ Aqueous, $\mathrm{EA}=$ Ethyl acetate, $\mathrm{C}=$ Control

\section{Discussion}

Aqueous extract did not show any antibacterial activity against all the bacteria studied. Similar results have been reported in the literature [13,14,15,16,17].

The difference in sensitivity might be ascribed to the difference in morphological constitutions between Gram-positive and Gram-negative organisms. Many plant species present inhibition zones of differing diameters; however, size difference of the inhibition zone depends primarily upon many factors for e.g. diffusion capacity of substances (present in the extracts) in the agar medium, antimicrobial activity of diffused substances, growth and metabolic activity of microorganisms in the medium. Inhibition zone diameter can further be associated with polarities of substances which make up the tested extracts, and also with cell wall composition of tested organisms since Gram-positive bacteria present cell walls with lower lipid levels than do Gramnegative bacteria [18]. 
Based on these results, it can be concluded that M. azedarach plant leaf extracts have potential as antimicrobial compounds against some microorganisms such as $S$. aureus and Candida albicans.

\section{References}

1. Afolayan, A.J. 2003. Extracts from the shoots of Arctotis artoides inhibit the growth of bacteria and fungi. Pharm. Biol. 14:22-25.

2. National Center for Complementary and Alternative Medicine. 2005. National Institutes of Health; Office of Dietary supplements. Available at:http://ods.od.gov/ factsheets/ Botanical Backgrounds.

3. Batcher, M.S. 2008. Element of Stewardship Abstract for Melia azedarach, TheNature Conservancy. Viewed 22 February, 2008, http://tncweeds.ucdavis.edu/esadocs/documents/meliaze.pdf $>$.

4. Bensky, D. and Gamble, A. 1986. Chinese Herbal Medicine Materia. Estland Press, Seattle.

5. Satyavati, G. V., Gupata, A.K. and Tandon, N. 1987. Medicinal plants of India Vol. 2: 226.

6. Khalid, A.m., El-Tawil, A.H., Ashy, M. and Elbeih, F.K. 1981. Constituents of local plants. Part-8: Distribution of some coumarins in plants of different plant families grown in Saudi Arabia. Pharmazia, 36(8): 569-571.

7. Baquar, S.R. 1989. Medicinal and Poisonous Plants of Pakistan. Printas, Karachi, pp. 279-280.

8. Simandi, B., Kery, A., Kristo, S.T. Andras, C. 2001. Supercritical fluid extraction of non-volatile terpenoids from medicinal plant. Acta. Pharma.hung. 71: 318-324.

9. Perez, C., Paul, M., Bazerque, P. 1990. An antibiotic assay by the agar well diffusion method. Acta Bio Med Exp. 15:113-5.

10. Parekh, J., Chanda, S. 2006. Screening of aqueous and alcoholic extracts of some Indian medicinal plants for antibacterial activity. Indian J Pharm Sci. 68:835-8.

11. Harborne, J.B. 1973. Phytochemical methods, London: Chapman and Hall Ltd. p.49-88.

12. Parekh, J., Chanda, S.2007. Antibacterial and phytochemical studies on twelve species of Indian medicinal plants. Afr J Biomed Res.10:175-81.

13. Idu, M., Oronsaye, F.E., Igeleke, C.L., Omonigho, S.E., Omogbeme, O.E., Ayinde, B.A. 2006. Preliminary investigation on the phytochemistry and antimicrobial activity of Senna alata L. leaves. J Appl Sci . 6:2481-5.

14. Kaneria, M., Baravalia, Y., Vaghasiya Y., Chanda. S. 2009. Determination of antibacterial and antioxidant potential of some medicinal plants from Saurashtra Region, India. Journal of Pharmaceutical Sciences. 7: 406-412.

15. OJ, Omogbai EKI, Obasuyi, O. 2007. Antifungal and antibacterial activities of the ethanolic and aqueous extract of Kigelia africana (Bignoniaceae) stem bark. Afr J Biotechnol. 6:1677-80.

16. Arnao, MB., Cano, A., Acosta, M. 2001.The hydrophilic and lipophilic contribution to total antioxidant activity. Food Chem. 73:239-44.

17. Masoko, A., Eloff, JN. 2007. Screening of twenty four South African Combretum and six Terminalia species (Combretaceae) for antioxidant activities. Afr J Trad CAM . 4: 231-9.

18. Bandeira MF, Teixeira MF, Abinader CD, Parente RC, Lima PS. Avaliay in vitro da sensibilidade da Candida albicans ao hidroxido de calcio associado ao oleo de copavba. Rev Dentvstica 2006; 6:12-22. 